высокой добавленной стоимостью, относящиеся к реальному сектору национальной экономики.

Эти меры позволят сформировать благоприятную деловую среду, повысить инвестиционную привлекательность Российской Федерации и в целом - укрепить национальную безопасность нашей страны, достичь и закрепить за собой титул лидирующей мировой державы.

Важнейшие угрозы экономической безопасности России динамичны, подвержены влиянию многочисленных факторов, а также не всегда выражаются в открытой форме. Для их ликвидации требуется проведение продуманной, законодательно подкрепленной и хорошо организованной на разных административных уровнях государственной политики, обязательно включающей в себя главный аспект - стратегию о безопасности, рассчитанную на долгосрочную перспективу. Выявление угроз на ранней стадии с помощью различных методов и механизмов, разработанных и внедренных в рамках государственной политики, позволяет с наименьшими рисками достичь их полного устранения и, таким образом, обеспечить экономическую безопасность Российской Федерации.

$$
* * *
$$

1. Глазьев C. Экономическая безопасность России: необходимые меры [Электронный ресурс]. - URL: http://politobzor.net/show-28866-ekonomicheskaya-bezopasnostrossii-neobhodimye-mery.html.

2. Путин утвердил стратегию экономической безопасности России до 2030 года // от 15 мая 2017 года // Стратегия экономической безопасности России // МИА «Россия сегодня». Режим доступа: https://ria.ru/economy/20170515/1494281108.html.

3. Указ Президента Российской Федерации от 13.05 .2017 г. № 208 «О Стратегии экономической безопасности Российской Федерации на период до 2030 года» // СПС «Консультант - Плюс». Режим доступа: http://www.consultant.ru/document/cons_doc_LAW_216629/.

4. Харич Е. А., Мамий С. А. Угрозы экономической безопасности России // Молодой ученый. 2016. №8.8. C. 35-37. Режим доступа: https://moluch.ru/archive/112/28835/.

5. Экономическая безопасность России: понятие, структура, сравнительная и перспективная оценка // АНО "Центр стратегических оценок и прогнозов". Режим доступа: http://csef.ru/ru/politica-igeopolitica/477/ekonomicheskaya-bezopasnost-rossii-ponyatie-struktura-sravnitelnaya-i-perspektivnayaoczenka-905.

\title{
Решеткина М.A. \\ Основные проблемы государственного финансового контроля в Российской Федерации
}

Ростовский государственный экономический университет (РИНХ)

(Россия, Ростов-на-Дону)

doi: 10.18411/lj-30-11-2017-07

idsp: 000001:lj-30-11-2017-07

\section{Аннотация}

В статье обозначены основные проблемы, возникающие при осуществлении государственного финансового контроля в Российской Федерации.

Ключевые слова: финансы, государственный финансовый контроль, бюджетные средства, эффективность бюджетных расходов.

Современные условия развития экономики, а также российского общества предъявляют жесткие требования к эффективности решения вопросов управления сферой, которая связана с реализацией задач контроля использования государственных и муниципальных финансовых ресурсов. В настоящее время финансовый контроль должен быть направлен на ускорение социального и экономического развития, пресечение бесхозяйственности и хищений, проверку своевременности выполнения обязательств перед бюджетом и внебюджетными фондами. С его помощью возможно решение вопросов сохранности денежных средств и материальных ценностей государства, 
использования государственных финансовых ресурсов по целевому назначению. Но в организации финансового контроля имеют место целый ряд проблем и противоречий, которые негативным образом сказываются на качестве, а также эффективности государственного финансового контроля.

Основными проблемами в организации эффективного финансового контроля являются: отсутствие четкой иерархичной системы органов, осуществляющих финансовый контроль, механизма их взаимодействия, пробелы в законодательном определении их компетенции. По мнению Р.В. Колесова и А.В. Юрченко серьезной преградой для успешного осуществления экономических реформ является достаточно громоздкая структура органов государственного финансового контроля. Задачи органов государственного финансового контроля недостаточно конкретны, границы их ответственности размыты, а деятельность координируется слабо. Они должны более тесно взаимодействовать между собой при сохранении ответственности каждого органа за свой участок контроля. Данную задачу, по их мнению, возможно решить путем дальнейшего укрепления правового статуса уже существующей Счетной палаты РФ. Также нужно отметить, что Президент Российской Федерации в своих посланиях неоднократно определял задачи в части всеобъемлющего изменения подходов к осуществлению государственного и муниципального финансового контроля, четкого разграничения полномочий и ответственности органов государственного и муниципального контроля, устранения дублирования и параллелизма в их работе.

Что касается усовершенствования действующего законодательства, то представляется, что внесение изменений в действующие нормативно-правовые акты может оказаться недостаточно эффективной мерой. В связи с этим, решение указанных правовых проблем должно найти свое отражение на уровне нового федерального закона «О государственном финансовом контроле», в котором необходимо отразить понятие, виды, цели, принципы и задачи финансового контроля, методы и формы его проведения. А также в нем необходимо закрепить систему органов финансового контроля, охарактеризовать их полномочия и компетенцию.

В продолжение указанных проблем нужно отметить, что другим заметным недостатком является недостаточная информационная открытость контрольных органов. В связи с этим не теряет свою актуальность проблема реализации прав на получение информации субъектами финансовых отношений, которую затрагивает в своих работах С.Е. Прокофьев, заместитель руководителя Федерального казначейства. Им указывается, что в части развития системы контроля в своей работе Казначейство России считает очень важным упорядочение системы предоставления информации. Но проблема формирования единого интегрированного информационного ресурса для более эффективной реализации функций и полномочий контрольных органов государства, по мнению С.Е. Прокофьева, пока еще не решена. Автор предлагает предпринять попытки к развитию Государственной информационной системы с условным названием «Госконтроль», где по аналогии с другими успешно функционирующими информационными ресурсами, его пользователям будет обеспечен доступ к необходимому массиву данных для совместного ее использования не только контрольно-надзорными органами, но и иными структурами власти и управления. Публичными также должны стать процессы планирования контрольных мероприятий и их результаты.

Специалистов в сфере финансового права также волнует коррупционный элемент в осуществлении финансового контроля. Так, О.Г. Геймур указывает, что, к сожалению, сложившаяся система финансового контроля в Российской Федерации недостаточно хорошо обеспечивает рациональное и целевое использование бюджетных средств, что связано с относительно высоким уровнем коррупции в стране. В связи с этим она предлагает увеличить штрафные санкции, налагаемые на организации за нецелевое использование бюджетных средств; навсегда запретить лицам, ранее привлеченным к 
ответственности за нецелевое использование бюджетных средств, занимать руководящие посты в бюджетных учреждениях и организациях.

На основе вышеизложенного можно сделать вывод о том, что в вопросах осуществления финансового контроля государственными органами имеется много «пробелов», которые, несомненно, создают препятствия для эффективной реализации его на практике. Решение указанных проблем может быть найдено путем совершенствования нормативно-правовой базы в сфере финансового контроля, а также путем внедрения новых методик, систем и механизмов в работу контрольных органов РФ.

$$
* * *
$$

1. Геймур О.Г. Правовое регулирование финансового контроля в Российской Федерации на современном этапе //Вестник Тюменского государственного университета. - 2014. - №3. - С. 133-140

2. Заседание коллегии Счетной Палаты [Электронный ресурс] // URL: http://kremlin.ru/events/president/news/47532 (дата обращения: 13.03.2016).

3. Колесов Р.В. Система государственного финансового контроля РФ: проблемы и перспективы: Монография / Р.В. Колесов, А.В. Юрченко. - Ярославль: ЯФ МФЮА, 2013. - С. 99

4. Прокофьев С.Е. Новации в сфере государственного финансового контроля, осуществляемого Казначейством России // Финансы и кредит. - 2015. - №10. - С. 2-11.

5. Карепина О.И. Проблемы организации внешнего муниципального финансового контроля//Международное научное издание Современные фундаментальные и прикладные исследования. 2017. № 3 (26). С. 76-80.

6. Ivanova O.B., Bogoslavtseva L.V., Karepina O.I., Kostoglodova E.D. Providing the budget transparency and state projects efficiency monitoring in Russia//European Research Studies Journal. 2017. T. 20. № 1. C. 97104. 